\title{
Also by Quentin Falk
}

Travels in Greeneland: The Cinema of Graham Greene, Quartet Books, 1984; revised and updated 1990; 3rd edition revised and updated, Reynolds \& Hearn, 2000; $4^{\text {th }}$ edition revised and updated, UPNG, 2014

The Golden Gong: Fifty Years of the Rank Organisation, Its Films and Its Stars, Columbus Books, 1987

Last of a Kind: The Sinking of Lew Grade (with Dominic Prince), Quartet Books, 1987

Anthony Hopkins: Too Good to Waste, Columbus Books, 1989; 5th edition revised and updated, Virgin Books, 2004

Albert Finney: In Character, Robson Books, 1992; 3rd edition revised and updated, Endeavour Press (online only), 2015

Cinema's Strangest Moments, Robson Books, 2003

Television's Strangest Moments (with Ben Falk), Robson Books, 2005

Mr Hitchcock, Haus Publishing, 2007

The Musical Milkman Murder, Blake Publishing, 2012

Mr Midshipman VC: The Short, Accident-Prone Life of George Drewry, Gallipoli Hero, Pen \& Sword, 2018 